\title{
PENGEMBANGAN BUKU AJAR MATA KULIAH PENDIDIKAN IPS UNTUK PGMI MENGGUNAKAN EXPANDING COMMUNITY APPROACH
}

\author{
M. Irfan Islamy \\ PGMI, Universitas Islam Negeri Maulana Malik Ibrahim \\ Malang, Indonesia \\ irfan.islamy87@uin-malang.ac.id
}

\begin{abstract}
This research is a continuation of the research on the Development of Textbooks for Social Studies Courses with the 2013 Curriculum Based Concept Approach. Development with Expanding Community Approach is used to create a hierarchical material that starts from a simple concept to a broader concept while paying attention to the distribution of Social Studies material at the level of Elementary School based on the 2013 Curriculum. Research \& development of textbooks for social studies education MI / SD with Expanding Community Approach aims to develop social studies textbooks in the Elementary School Teacher Education department that can be used as learning resources for students in Social Studies courses. This development research uses the Thiarajagan 4-D model with the steps of Define, Design, Develop, and restrictions on Desseminate. Research on the development of Social Studies course textbooks for Elementary School Teacher Education with Expanding Community Approach received a very decent category with a score of $81 \%$ from material experts, a decent category with a score of $80 \%$ from linguists, and a very decent category with a score of $87 \%$ from design experts. The data can provide the conclusion that the textbooks of Social Studies courses using the expanding community approach are categorized as feasible.
\end{abstract}

Keywords: Development of Textbooks; Social Studies; Expanding Community Approach 


\section{Abstrak}

Penelitian ini merupakan lanjutan dari penelitian Pengembangan Buku Ajar Mata Kuliah Pendidikan IPS MI/SD dengan Pendekatan Konsep Berbasis Kurikulum 2013. Pengembangan dengan Expanding Community Approach digunakan untuk membuat sebuah hirarkis materi yang dimulai dari konsep sederhana menjadi konsep yang lebih luas dengan tetap memperhatikan sebaran materi IPS pada jenjang MI/SD berdasarkan Kurikulum 2013. Penelitian \& pengembangan buku ajar mata kuliah Pendidikan IPS MI/SD dengan Expanding Community Approach bertujuan untuk mengembangkan buku ajar mata kuliah Pendidikan IPS pada jurusan PGMI yang dapat dijadikan sumber belajar untuk mahasiswa pada mata kuliah Pendidikan IPS. Penelitian pengembangan ini menggunakan model 4-D Thiarajagan dengan tahapan Define, Design, Develop, dan pembatasan pada Desseminate. Penelitian pengembangan buku ajar mata kuliah Pendidikan IPS untuk PGMI dengan Expanding Community Approach mendapatkan kategori sangat layak dengan skor $81 \%$ dari ahli materi, kategori layak dengan skor $80 \%$ dari ahli bahasa, dan kategori sangat layak dengan skor $87 \%$ dari ahli desain. Data tersebut dapat memberikan kesimpulan bahwa buku ajar mata kuliah Pendidikan IPS menggunakan pendekatan expanding community dikategorikan layak.

Kata Kunci: Pengembangan Buku Ajar; Pendidikan IPS; Expanding Community Approach

\section{PENDAHULUAN}

Ilmu Pengetahuan Sosial (IPS) merupakan mata pelajaran tentang ilmu-ilmu sosial yang disederhanakan ${ }^{1}$ dalam rangka keberhasilan Pendidikan ${ }^{2}$. IPS disajikan dengan bentuk studi sosial dan kemasyarakatan pada jenjang Sekolah Dasar dengan tujuan

${ }^{1}$ Robert D Barr, James L Barth, and S Samuel Shermis, Defining the Social Studies (National Council for the Social Studies Washington, DC, 1977); Edy Surahman and M. Mukminan, "Peran guru IPS sebagai pendidik dan pengajar dalam meningkatkan sikap sosial dan tanggung jawab sosial siswa SMP," Harmoni Sosial: Jurnal Pendidikan IPS 4, no. 1 (October 16, 2017): 1, https://doi.org/10.21831/hsjpi.v4i1.8660; E Wayne Ross, Social Studies Curriculum, The: Purposes, Problems, and Possibilities (Suny Press, 2014).

2 Dr Sapriya, "Pendidikan IPS," Bandung: PT. Remaja Rosdakarya, 2009. 
memberikan kompetensi sosial kepada peserta didik berdasarkan kesesuaian karakteristik dan kerangka berpikir peserta didik pada jenjang Sekolah Dasar. Sajian materi pada mata pelajaran IPS diharapkan dapat membantu para peserta didik dalam membangun potensi diri mereka terhadap dinamika sosial kemasyarakatan yang terus berkembang ${ }^{3}$, yang bermanfaat bagi individu dan masyarakat ${ }^{4}$, sehingga dapat membentuk karakter warga negara yang baik (good citizenship) ${ }^{5}$.

Dinamika kehidupan masyarakat yang sangat dinamis, tentu membawa perubahan pada setiap hasil evaluasi kurikulum Pendidikan di Indonesia. Perubahan tersebut juga berdampak pada kompetensi yang disajikan di semua jenjang Pendidikan, termasuk pada jenjang Sekolah Dasar. IPS yang pada awalnya disajikan secara terpisah dengan mata pelajaran lainnya dari kelas 1 sampai dengan IV, kemudian disajikan secara tematik dengan hadirnya kurikulum 2013. Materi IPS secara spesifik hanya terdapat pada kompetesi dasar di Kelas IV sampai dengan Kelas VI SD/MI.

Perkembangan tersebut merupakan dasar dalam mengembangkan materi yang disajikan pada mata kuliah IPS pada jurusan Pendidikan Guru Madrasah Ibtidaiyah (PGMI) atau Pendidikan Guru Sekolah Dasar (PGSD), sebagai jurusan yang secara khusus mencetak calon guru kelas dengan kompetensi pada penguasaan 5 mata pelajaran wajib, yaitu Matematika, IPA, PPKn, Bahasa Indonesia, dan IPS. Dari perkembangan kurikulum tersebut, tentu membawa pengaruh pada Mata Kuliah IPS yang disajikan pada jurusan PGMI/PGSD, khususnya pada perangkat pembelajaran ${ }^{6}$. Salah satu perangkat

3 Miftahuddin Miftahuddin, "Revitaslisasi IPS Dalam Perspektif Global," Jurnal Pemikiran Keislaman 27, no. 2 (September 5, 2016): 267 284-267 284, https://doi.org/10.33367/tribakti.v27i2.269.

${ }^{4}$ Anastasia Endah Anastika Dewi and Mukminan Mukminan, "Implementasi Pendekatan Saintifik Dalam Pembelajaran IPS Di Middle Grade SD Tumbu 3 Kota," Jurnal Prima Edukasia 4, no. 1 (February 9, 2016): 20-31, https://doi.org/10.21831/jpe.v4i1.7691.

${ }^{5}$ Ratna Puspitasari, "Penanaman Nilai Karakter Peduli Lingkungan Dalam Muatan Enviromental Education Pada Pembelajaran IPS DI MI Darul Hikam Kota Cirebon," Al Ibtida: Jurnal Pendidikan Guru MI 3, no. 1 (June 10, 2016), https://doi.org/10.24235/al.ibtida.snj.v3i1.547.

${ }^{6}$ Eni Cahya Wijayati, I. Nyoman Sudana Degeng, and Sumarmi Sumarmi, "Kesulitan-Kesulitan dalam Implementasi Kurikulum Mata Pelajaran IPS SMP," 
pembelajaran yang sangat dibutuhkan adalah bahan ajar, yang berfungsi sebagai rujukan referensi dan keilmuan dalam perkuliahan ${ }^{7}$. Bahan ajar digunakan untuk mempelajari kompetensi yang akan diimplementasikan dalam proses pembelajaran ${ }^{8}$, .

Jenis bahan ajar yang sangat diperlukan dalam pembelajaran adalah adalah buku ajar. Buku ajar berfungsi sebagai dasar acuan dalam memulai, melaksanakan, mengevaluasi, dan pengembangan proses pembelajaran di kelas ${ }^{10}$. Buku ajar akan menjadi penentu dan penyampaian pesan dalam mewujudkan ketertarikan, motivasi, dan indikator kesuksesan dalam mencapai kompetensi pada pembelajaran ${ }^{11}$. Buku ajar yang tersedia, akan meminimalisir mahasiswa dalam mehahami konsep dan teori dalam pembelajaran ${ }^{12}$, selain pengaruh kepada motivasi mahasiswa dalam proses pembelajaran ${ }^{13}$.

Jurnal Pendidikan: Teori, Penelitian, dan Pengembangan 1, no. 11 (November 1, 2016): 2241-47, https://doi.org/10.17977/jp.v1i11.8132.

${ }^{7}$ Nugroho Aji Prasetiyo and Pertiwi Perwiraningtyas, “The Development of Environment based Textbook in Biology Course at Tribhuwana Tunggadewi University," Jurnal Pendidikan Biologi Indonesia 3, no. 1 (March 31, 2017): 19, https://doi.org/10.22219/jpbi.v3i1.3969.

8 Nurjannah Nurjannah, "Pengembangan Pembelajaran IPS Berwawasan Kebangsaan Sebagai Matakuliah Jati Diri Di Fakultas Ilmu Sosial UNIMED," JUPIIS: JURNAL PENDIDIKAN ILMU-ILMU SOSIAL 9, no. 2 (December 28, 2017): 133-40, https://doi.org/10.24114/jupiis.v9i2.8241.

${ }^{9}$ Saiful Amin, "Pengembangan Bahan Ajar Geografi Terintegrasi Sains Islam di Madrasah," Jurnal Pendidikan: Teori, Penelitian, dan Pengembangan 2, no. 7 (July 1, 2017): 934-45, https://doi.org/10.17977/jptpp.v2i7.9676.

10 Erna Suwarni, "PENGEMBANGAN BUKU AJAR BERBASIS LOKAL MATERI KEANEKARAGAMAN LABA-LABA DI KOTA METRO SEBAGAI SUMBER BELAJAR ALTERNATIF BIOLOGI UNTUK SISWA SMA KELAS X," BIOEDUKASI (Jurnal Pendidikan Biologi) 6, no. 2 (November 1, 2015), https://doi.org/10.24127/bioedukasi.v6i2.336.

${ }^{11}$ Dina Fitrohtur Rohmah, Hariyono Hariyono, and Sudarmiatin Sudarmiatin, "Pengembangan Buku Ajar IPS SD Berbasis Kontekstual," Jurnal Pendidikan: Teori, Penelitian, dan Pengembangan 2, no. 5 (May 1, 2017): 719-23, https://doi.org/10.17977/jptpp.v2i5.9200.

12 Nia Ulfia Krismawati, Warto Warto, and Nunuk Suryani, "Analisis Kebutuhan pada Bahan Ajar Penelitian dan Penulisan Sejarah di Sekolah Menengah Atas (SMA)," Briliant: Jurnal Riset dan Konseptual 3, no. 3 (August 13, 2018): 300311, https://doi.org/10.28926/briliant.v3i3.202.

${ }^{13}$ Lukman Lukman and Ishartiwi Ishartiwi, "PENGEMBANGAN BAHAN AJAR DENGAN MODEL MIND MAP UNTUK PEMBELAJARAN ILMU PENGETAHUAN SOSIAL SMP," Jurnal Inovasi Teknologi Pendidikan 1, no. 2 
Pengembangan ini didasarkan pada kebutuhan mahasiswa pada prodi PGMI Fakultas Ilmu Tarbiyah dan Keguruan (FITK) UIN Malang pada mata kuliah Pendidikan IPS terhadap buku ajar yang relevan dan rujukan referensi mereka dalam belajar ${ }^{14}$. Pengembangan ini menggunakan pendekatan Community Approach sebagai lanjutan pada pengembangan buku ajar Pendidikan IPS menggunakan pendekatan Konsep ${ }^{15}$. Pendekatan konsep diperlukan untuk memetakan konsepkonsep Ilmu-Ilmu sosial yang terdapat pada Kompetensi Dasar mata pelajaran IPS pada jenjang Sekolah Dasar/Madrasah Ibtidaiyah berdasarkan kurikulum 2013, dengan tujuan menyamakan persepsi dan menghindari miskonsepsi ${ }^{16}$. Pendekatan Expanding Community merupakan pendekatan dalam mengembangkan materi pembelajaran yang di mulai dari konsep sederhana, kemudian ditingkatkan menjadi konsep yang lebih kompleks atau rumit ${ }^{17}$. Pendekatan Expanding Community yang digunakan bertujuan memandu mahasiswa dalam memahami materi pembelajaran yang disajikan pada mata kuliah Pendidikan IPS secara utuh dan terpadu.

(2014): 109-22, https://doi.org/10.21831/tp.v1i2.2523; Agus Riwanda, Armin Fani, and M Irfan Islamy, "A CORRELATION BETWEEN THE USE OF INTERNET AS LEARNING SOURCE, LEARNERS'LEARNING AUTONUMOUS AND LEARNERS'ENGAGEMENT IN LEARNING PROCESS,” vol. 2, 2017, 299-307.

${ }^{14}$ M. Irfan Islamy, "Developing Concept Approach Based Textbooks of Social Sciences Course for Madrasah Ibtidaiyah Teacher Education," Al Ibtida: Jurnal Pendidikan Guru MI 6, no. 1 (June 30, 2019): 90-109, https://doi.org/10.24235/al.ibtida.snj.v6i1.3594.

${ }^{15}$ Islamy.

${ }^{16}$ Mosik - and P. Maulana, "Usaha Mengurangi Terjadinya Miskonsepsi Fisika Melalui Pembelajaran dengan Pendekatan Konflik Kognitif," Jurnal Pendidikan Fisika Indonesia 6, no. 2 (2010), https://doi.org/10.15294/jpfi.v6i2.1120; Izza Auliyatul Muna, "Identifikasi Miskonsepsi Mahasiswa PGMI Pada Konsep Hukum Newton Menggunakan Certainty of Response Index (CRI)," Cendekia: Jurnal Kependidikan Dan Kemasyarakatan 13, no. 2 (April 4, 2016): 309-22, https://doi.org/10.21154/cendekia.v13i2.251; Mursalin, "Meminimalkan Miskonsepsi Pada Materi Rangkaian Listrik Dengan Pembelajaran Predict-Observe-Explain," Jurnal Ilmu Pendidikan 20, no. 1 (2014), https://doi.org/10.17977/jip.v20i1.4383; Endang Susilaningsih, Kasmui Kasmui, and Harjito Harjito, "Desain Instrumen Tes Diagnostik Pendeteksi Minkonsepsi Untuk Analisis Pemahaman Konsep Kimia Mahasiswa Calon Guru," Unnes Science Education Journal 5, no. 3 (2016), https://doi.org/10.15294/usej.v5i3.13184.

${ }^{17}$ David A Jacobsen, Paul D Eggen, and Donald P Kauchak, Methods for Teaching: Promoting Student Learning (Merrill/Prentice Hall, 2002). 


\section{METODE PENELITIAN}

Jenis penelitian yang digunakan adalah Research and Development (R\&D). R\&D digunakan untuk menghasilkan kebaharuan sebuah produk yang tervalidasi layak, dalam penelitian pengembangan ini, produk yang akan dikembangkan adalah buku ajar mata kuliah Pendidikan IPS untuk mahasiswa pada jurusan PGMI/PGSD. Model pengembangan yang digunakan adalah model 4-D (Four D), yang dikembangkan oleh Thiagarajan ${ }^{18}$. Terdapat 4 tahap prosedur dalam model 4D, yaitu: Pendefenisian (Define), Perancangan (Design), Pengembangan (Develop), Penyebaran (Disseminate)

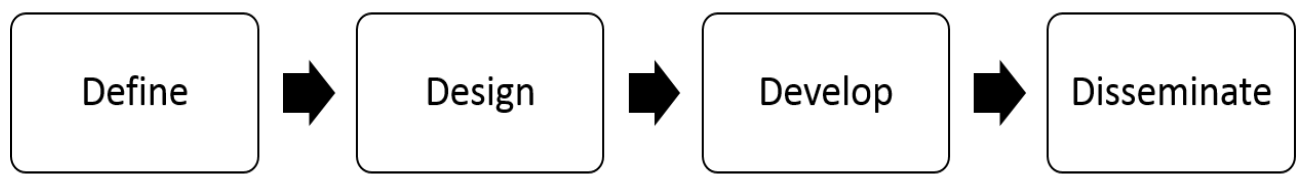

Gambar 1. Tahap Pengembangan Model 4-D

Pengembangan buku ajar Pendidikan IPS ini hanya menerapkan 3 tahap 3 tahap utama, yaitu:

1. Define (Pendefenisian). tahap ini memastikan peta konsep-konsep ilmu sosial yang telah dikembangkan pada penelitian sebelumnya sesuai dengan kompetensi dasar IPS pada jenjang SD/MI berdasarkan kurikulum 2013.

2. Design (Desain). Desain yang dimaksud adalah mengembangkan hirarkis materi pada konsep-konsep ilmu sosial yang terdapat pada kompetensi dasar IPS pada jenjang SD/MI berdasarkan kurikulum 2013, dengan menggunakan pendekatan Expanding Communtiy.

3. Develop (Pengembangan). Desain yang telah disusun kemudian diserahkan kepada ahli materi, ahli bahasa, dan ahli desain media untuk validasi kelayakan produk, kemudian dilakukan revisi pengembangan sesuai permintaan ahli.

Untuk mendapatkan data validasi kelayakan produk, penelitian pengembangan buku ajar Pendidikan IPS ini menggunakan analisis skor skala likert. Skala likert yang digunakan berdasarkan kriteria yang ditetapkan, kemudian ditampilkan secara persentase (\%) berdasarkan hasil validasi kelayakan produk oleh para ahli. Rumus yang digunakan

${ }^{18}$ Sivasailam Thiagarajan, "Instructional Development for Training Teachers of Exceptional Children: A Sourcebook.," 1974. 
untuk mendapat formula presentasi pada masing-masing hasil validasi ahli dapat ditampilkan sebagai berikut:

$$
\text { persentase (\%) }=\frac{\sum \text { (keseluruhan skor jawaban angket) }}{\mathrm{N} \times \mathrm{n} \times \text { bobot tertinggi }} \times 100 \%
$$

Keterangan:

$\mathrm{N}=$ jumlah responden

$\mathrm{n}=$ jumlah seluruh item angket

Tabel 1. Kriteria Persentase Kelayakan Produk Buku Ajar Pendidikan IPS

\begin{tabular}{lll}
\hline Tingkat Pencapaian (\%) & Kualifikasi & Keterangan \\
\hline $86-100$ & Sangat layak & Tidak Perlu Revisi \\
$71-85$ & Layak & Tidak Perlu Revisi \\
$56-70$ & Cukup layak & Revisi \\
$41-55$ & Kurang layak & Revisi \\
$0-40$ & Sangat Tidak Layak & Revisi \\
\hline
\end{tabular}

\section{HASIL DAN PEMBAHASAN \\ Define (Penegasan)}

1. Analisis ujung depan (front end analysis). Tahap ini untuk memetakan permasalahan dasar terdapat penelitian pengembangan yang di lakukan. Permasalahan dasar yang dijadikan alasan untuk melakukan pengembangan adalah perkembangan kurikulum Sekolah Dasar IPS SD/MI, yang menjadi acuan dalam pengembangan pembelajaran pada mata kuliah Pendidikan IPS di jurusan PGMI. Kurangnya referensi yang terpadu pada mata kuliah Pendidikan IPS untuk PGMI yang menjadi rujukan referensi mahasiswa, dan sebagai bahan pengembangan lanjutan pada penelitian sebelumnya ${ }^{19}$.

2. Analisis siswa (learner analysis). Pengembangan buku ajar ini diperuntukkan untuk mahasiswa yang mengambil mata kuliah Pendidikan IPS pada jurusan PGMI.

3. Analisis tugas (task analysis). Pada tahap ini, analisis tugas didefinisakan sebagai kompentesi dasar dengan istilah yang digunakan adalah learning outcomes. Learning outcomes merupakan capaian pembelajaran yang harus ditempuh dan dikuasi

${ }^{19}$ Islamy, "Developing Concept Approach Based Textbooks of Social Sciences Course for Madrasah Ibtidaiyah Teacher Education." 
oleh mahasiswa PGMI pada mata kuliah Pendidikan IPS.

4. Analisis konsep (concept analysis). Konsep yang diterapkan ini adalah hasil pengembangan materi berdasarkan pendekatan konsep, yaitu konsep-konsep ilmu-ilmu sosial yang telah berhasil dikembangkan berdasarkan kurikulum 2013 Revisi 2016/2017 sesuai Permendikbud No 21 Tahun 2016. Konsep-konsep ilmu sosial tersebut akan menjadi konsep inti yang didasarkan pada kompetensi dasar pengetahuan (kognitif) mata pelajaran IPS SD/MI Kelas IV, V, dan VI yang dapat dilihat pada tabel 2. Berangkat dari konsep inti tersebut, kemudian pengembangan materi menggunakan pendekatan Expanding Community.

Tabel 2. Konsep Inti KI \& KD Pengetahuan IPS MI/SD Kelas $4{ }^{20}$

\begin{tabular}{|c|c|c|c|}
\hline $\begin{array}{l}\text { Kom } \\
\text { (KI) }\end{array}$ & & Kompetensi Dasar (KD) & $\begin{array}{l}\text { Konsep } \\
\text { Inti }\end{array}$ \\
\hline \multirow{4}{*}{$\begin{array}{l}\text { Memahami } \\
\text { pengetahuan } \\
\text { faktual dengan cara } \\
\text { mengamati dan } \\
\text { menanya } \\
\text { berdasarkan rasa } \\
\text { ingin tahu tentang } \\
\text { dirinya, makhluk } \\
\text { ciptaan Tuhan dan } \\
\text { kegiatannya, dan } \\
\text { benda-benda yang } \\
\text { dijumpainya di } \\
\text { rumah, di sekolah } \\
\text { dan tempat bermain }\end{array}$} & & \begin{tabular}{lcc} 
Mengidentifikasi & \multicolumn{2}{c}{ karakteristik } \\
ruang dan pemanfaatan sumber \\
daya alam untuk kesejahteraan \\
masyarakat & dari & tingkat \\
kota/kabupaten sampai & tingkat \\
provinsi & & \\
\end{tabular} & $\begin{array}{l}\text { 1. Ruang } \\
\text { 2. Sumber } \\
\text { daya } \\
\text { alam }\end{array}$ \\
\hline & 2 & $\begin{array}{l}\text { Mengidentifikasi keragaman } \\
\text { sosial, ekonomi, budaya, etnis dan } \\
\text { agama di provinsi setempat } \\
\text { sebagai identitas bangsa Indonesia }\end{array}$ & $\begin{array}{l}\text { Keragama } \\
\mathrm{n} \text { sosial, } \\
\text { ekonomi, } \\
\text { budaya, } \\
\text { etnis, dan } \\
\text { agama }\end{array}$ \\
\hline & 3.3 & $\begin{array}{l}\text { Mengidentifikasi } \\
\text { ekonomi dalam meningkatkan } \\
\text { kehidupan masyarakat di bidang } \\
\text { pekerjaan, sosial dan budaya di } \\
\text { lingkungan sekitar sampai } \\
\text { provinsi }\end{array}$ & $\begin{array}{l}\text { 1. Kegiat } \\
\text { an } \\
\text { ekono } \\
\text { mi } \\
\text { 2. Pekerj } \\
\text { aan }\end{array}$ \\
\hline & 3.4 & $\begin{array}{l}\text { Mengidentifikasi kerajaan Hindu, } \\
\text { Buddha dan Islam serta } \\
\text { pengaruhnya pada kehidupan }\end{array}$ & $\begin{array}{l}\text { 1. Keraja } \\
\text { an } \\
\text { Hindu }\end{array}$ \\
\hline
\end{tabular}

${ }^{20}$ Islamy. 
AL-MUDARRIS:journal of education, Vol. 2. No. 2 Oktober 2019, ISSN: 2620-5831 (print), ISSN: 2620-4355(online)

DOI: $10.32478 /$ al-mudarris.v\%vi\%i.271

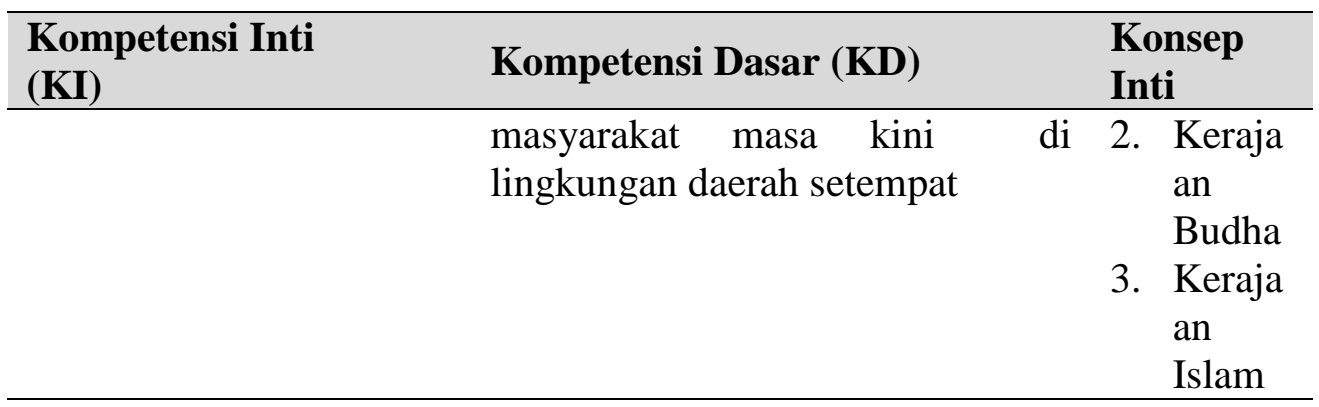

Tabel 3. Konsep Inti KI/KD Pengetahuan IPS MI/SD Kelas $5^{21}$

\begin{tabular}{|c|c|c|}
\hline Kompetensi & Kompetensi Dasar (KD) & Konsep Inti \\
\hline \multirow{4}{*}{$\begin{array}{l}\text { Memahami } \\
\text { pengetahuan } \\
\text { faktual dan } \\
\text { konseptual } \\
\text { dengan cara } \\
\text { mengamati, } \\
\text { menanya dan } \\
\text { mencoba } \\
\text { berdasarkan } \\
\text { rasa ingin tahu } \\
\text { tentang dirinya, } \\
\text { makhluk } \\
\text { ciptaan Tuhan } \\
\text { dan } \\
\text { kegiatannya, } \\
\text { dan benda- } \\
\text { benda yang } \\
\text { dijumpainya di } \\
\text { rumah, di } \\
\text { sekolah dan di } \\
\text { tempat } \\
\text { bermain. }\end{array}$} & $\begin{array}{ll} & \text { Mengidentifikasi karakteristik } \\
\text { geografis Indonesia sebagai } \\
\text { negara kepulauan/maritim } \\
\text { 3.1 } \\
\text { dan agraris serta pengaruhnya } \\
\text { terhadap kehidupan ekonomi, } \\
\text { sosial, budaya, komunikasi } \\
\text { serta transportasi }\end{array}$ & $\begin{array}{l}\text { 1. Karakteristik } \\
\text { Geografis } \\
\text { 2. Negara } \\
\text { kepulauan/mari } \\
\text { tim dan agraris }\end{array}$ \\
\hline & $\begin{array}{l}\text { Menganalisis bentuk-bentuk } \\
\text { interaksi manusia dengan } \\
\text { 3.2 lingkungan dan pengaruhnya } \\
\text { terhadap pembangunan sosial, } \\
\text { budaya dan ekonomi } \\
\text { masyarakat Indonesia }\end{array}$ & $\begin{array}{l}\text { 1. Interaksi } \\
\text { manusia dan } \\
\text { lingkungan } \\
\text { 2. Pembangunan } \\
\text { sosial, budaya, } \\
\text { dan ekonomi }\end{array}$ \\
\hline & $\begin{array}{l}\text { Menganalisis peran ekonomi } \\
\text { dalam upaya menyejahterakan } \\
\text { kehidupan masyarakat di } \\
\text { bidang sosial dan budaya } \\
\text { untuk memperkuat kesatuan } \\
\text { dan persatuan bangsa }\end{array}$ & $\begin{array}{l}\text { 1. Peran \& fungsi } \\
\text { ekonomi } \\
\text { 2. Kesatuan \& } \\
\text { persatuan } \\
\text { bangsa }\end{array}$ \\
\hline & $\begin{array}{l}\text { Mengidentifikasi faktor-faktor } \\
\text { penting penyebab penjajahan } \\
3.4 \text { bangsa Indonesia dan upaya } \\
\text { bangsa Indonesia dalam } \\
\text { mempertahankan }\end{array}$ & $\begin{array}{l}\text { 1. Penjajahan } \\
\text { 2. Mempertahank } \\
\text { an } \\
\text { kemerdekaan }\end{array}$ \\
\hline
\end{tabular}

${ }^{21}$ Islamy. 
AL-MUDARRIS:journal of education, Vol. 2. No. 2 Oktober 2019, ISSN: 2620-5831 (print), ISSN: 2620-4355(online)

DOI: $10.32478 /$ al-mudarris.v\%vi\%i.271

Kompetensi

Inti (KI)

Kompetensi Dasar (KD)

Konsep Inti

kedaulatannya

Tabel 4. Konsep Inti KI/KD Pengetahuan IPS MI/SD Kelas $6{ }^{22}$

\begin{tabular}{|c|c|c|c|}
\hline $\begin{array}{l}\text { Kompetensi Inti } \\
\text { (KI) }\end{array}$ & & Kompetensi Dasar (KD) & Konsep Inti \\
\hline $\begin{array}{l}\text { Memahami } \\
\text { pengetahuan } \\
\text { faktual dan }\end{array}$ & 3.1 & $\begin{array}{l}\text { Mengidentifikasi karakteristik } \\
\text { geografis dan kehidupan sosial } \\
\text { budaya, ekonomi, politik di } \\
\text { wilayah ASEAN }\end{array}$ & $\begin{array}{l}\text { 1. Karakteristik Geograf } \\
\text { 2. Asean }\end{array}$ \\
\hline $\begin{array}{l}\text { konseptual dengan } \\
\text { cara mengamati, } \\
\text { menanya dan }\end{array}$ & 3.2 & $\begin{array}{l}\text { Menganalisis perubahan sosial } \\
\text { budaya dalam rangka } \\
\text { modernisasi bangsa Indonesia }\end{array}$ & $\begin{array}{l}\text { 1. Perubahan Sosial } \\
\text { 2. Modernisasi }\end{array}$ \\
\hline $\begin{array}{l}\text { mencoba } \\
\text { berdasarkan rasa } \\
\text { ingin tahu tentang } \\
\text { dirinya, makhluk } \\
\text { ciptaan Tuhan dan } \\
\text { kegiatannya, dan }\end{array}$ & 3.3 & $\begin{array}{l}\text { Menganalisis posisi dan peran } \\
\text { Indonesia dalam kerjasama di } \\
\text { bidang ekonomi, politik, } \\
\text { sosial, budaya, teknologi dan } \\
\text { pendidikan dalam lingkup } \\
\text { ASEAN }\end{array}$ & $\mathrm{Neq}$ \\
\hline $\begin{array}{l}\text { benda-benda yang } \\
\text { dijumpainya di } \\
\text { rumah, di sekolah } \\
\text { dan di tempat } \\
\text { bermain }\end{array}$ & 3.4 & $\begin{array}{l}\text { Memahami makna proklamasi } \\
\text { kemerdekaan, upaya } \\
\text { mempertahankan } \\
\text { kemerdekaan, dan upaya } \\
\text { mengembangkan kehidupan } \\
\text { kebangsaan yang sejahtera }\end{array}$ & Proklam \\
\hline
\end{tabular}

\section{Design (Perancangan)}

Tahap design merupakan lanjutan dari tahap define. Pada tahap ini terdapat 4 langkah yang dilakukan, yaitu:

1. Menggunakan bentuk tes pilihan ganda pada setiap akhir materi pembelajaran, sebagai alat ukut ketercapaian pembelajaran.

2. Menggunakan bentuk media pembelajaran dalam bentuk grafik baik

$$
{ }^{22} \text { Islamy. }
$$


yang statis atau bergerak untuk mendukungan ketercapaian pembelajaran.

3. Bentuk bahan ajar yang dipilih, adalah buku ajar;

4. Rancangan awal merupakan rancangan buku ajar yang akan dikembangkan berpedoman pada kategori pada penelitian dengan menggunakan pendekatan konsep.

Konsep yang telah dipetakan, kemudian dikembangkan menggunakan Expanding Community Approach untuk mendapatkan sistematika materi yang akan disajikan pada produk. Hasil pengembangan konsep ke materi menggunakan Expanding Community Approach berdasarkan sajian materi IPS SD/MI kelas IV, V, dan VI dapat dilihat pada tabel 5 .

Tabel 5 Pengembangan Konsep dengan Pendekatan Expanding Community Approach (ECA)

\begin{tabular}{|c|c|c|}
\hline Kelas & Pemetaan Konsep & Pengembangan Konsep \\
\hline \multirow{20}{*}{4} & Ruang Sumber daya & 1. Konsep Dasar Peta \\
\hline & & 2. Konsep Ruang \\
\hline & & 3. Sumber Daya Alam \\
\hline & Keragaman & 1. Keragaman Sosial Budaya \\
\hline & ekonomi, & 2. Keragaman Ekonomi \\
\hline & etnis, dan agama & 3. Keragaman Etnis \\
\hline & & 4. Keragaman Agama \\
\hline & Kegiatan ekonomi & 1. Kegiatan Ekonomi \\
\hline & Pekerjaan & 2. Ketersediaan sumber-sumber \\
\hline & & ekonomi \\
\hline & & 3. Berbagai Pekerjaan \\
\hline & & 4. Kegiatan Ekonomi dan Lapangan \\
\hline & & Kerja \\
\hline & & 5. Lembaga Ekonomi \\
\hline & & $\begin{array}{l}\text { 6. Perniagaan untuk meningkatkan } \\
\text { kesejahteraan }\end{array}$ \\
\hline & Kerajaan Hindu & 1. Konsep dasar sejarah \\
\hline & Kerajaan Budha & 2. Keraajan Hindu Indonesia \\
\hline & Kerajaan Islam & 3. Kerajaan Budha Indonesia \\
\hline & & 4. Kerajaan Islam Indonesia \\
\hline & & $\begin{array}{l}\text { 5. Pengaruh Kerajaan Hindu, Budha, } \\
\text { dan Islam di Indonesia }\end{array}$ \\
\hline 5 & Karakter Geografis & 1. Letak dan Luas Indonesia dalam \\
\hline
\end{tabular}




\begin{tabular}{|c|c|c|}
\hline Kelas & Pemetaan Konsep & Pengembangan Konsep \\
\hline & Negara & Peta \\
\hline & kepulauan/maritim dan & 2. Kondisi Alam Wilayah Indonesia \\
\hline & agraris & 3. Karakteristik Kependudukan \\
\hline & & 4. Negara Kepulauan/maritime dan \\
\hline & & $\begin{array}{l}\text { 5. Pengaruh negara maritime dan } \\
\text { agraris terhadap kehidupan sosial } \\
\text { ekomomi dan budaya Indonesia }\end{array}$ \\
\hline & Interaksi manusia dan & 1. Interaksi sosial \\
\hline & lingkungan & 2. Interaksi sosial budaya \\
\hline & Pembangunan sosial, & 3. Interaksi manusia \\
\hline & budaya, dan ekonomi & lingkungan \\
\hline & & 4. Sosialisasi/ekulturasi \\
\hline & & 5. Pembangunan sosial budaya \\
\hline & & $\begin{array}{l}\text { 6. Pembangunan sosial budaya dan } \\
\text { ekonomi }\end{array}$ \\
\hline & Peran \& fungsi & 1. Konsep Dasar Ekonomi \\
\hline & ekonomi & 2. Kegiatan ekonomi masyarakat \\
\hline & Kesatuan \& persatuan & Indonesia \\
\hline & bangsa & $\begin{array}{l}\text { 3. Kegiatan ekonomi pada bidang } \\
\text { pertambangan dan industri }\end{array}$ \\
\hline & Penjajahan & 1. Konsep dasar imperialisme dan \\
\hline & Mempertahankan & kolonialisme \\
\hline & kemerdekaan & 2. Penjajahan bangsa Eropa di \\
\hline & & 3. Perlawanan bangsa Indonesia \\
\hline & & 4. Organisasi gerakan Nasional \\
\hline & & $\begin{array}{l}\text { 5. Pendudukan militer Jepang di } \\
\text { Indonesia }\end{array}$ \\
\hline & Karakteristik Geografis & 1. Asean \\
\hline & Asean & 2. Negara-negara ASEAN \\
\hline & & $\begin{array}{l}\text { 3. Karakteristik Geografis Wilayah } \\
\text { ASEAN }\end{array}$ \\
\hline 6 & & 4. Karakteristik kondisi \\
\hline & & Kawasan ASEAN \\
\hline & $\begin{array}{l}\text { Perubahan Sosial } \\
\text { Modernisasi }\end{array}$ & $\begin{array}{l}\text { 1. Perubahan Sosial Budaya di } \\
\text { Indonesia }\end{array}$ \\
\hline
\end{tabular}




\begin{tabular}{|c|c|c|}
\hline Kelas & Pemetaan Konsep & Pengembangan Konsep \\
\hline & & 2. Modernisasi dalam bidang \\
\hline & & $\begin{array}{l}\text { IPTEK, Ekonomi, Pendidikan, } \\
\text { dan Demokrasi }\end{array}$ \\
\hline & Kerjasama & 1. Ekspor dan Impor \\
\hline & negara ASEAN & $\begin{array}{l}\text { 2. Pengiriman Pertukaran Tenaga } \\
\text { Kerja }\end{array}$ \\
\hline & & 3. Masyarakat Ekonomi ASEAN \\
\hline & Proklamasi & 1. Proklamasi Kemerdekaan \\
\hline & kemerdekaan & $\begin{array}{l}\text { 2. Membangun kehidupan bangsa } \\
\text { yang berdaulat }\end{array}$ \\
\hline & & $\begin{array}{l}\text { 3. Peran bangsa } \\
\text { membangun }\end{array}$ \\
\hline & & Internasional \\
\hline
\end{tabular}

\section{Pengembangan Sistematika Materi dengan Expanding Community Approach (ECA)}

Berdasarkan tabel 4.4, konsep yang ditelah dikembangkan dapat dilanjutkan kepada penulisan sistematika materi. Hasil pengembangan sistematika materi dengan expanding community approach (ECA) berdasarkan KI \& KD Kelas 4, 5, dan 6 IPS SD/MI pada tabel 6, 7, dan 8 .

Tabel 6 Pengembangan Sistematika Materi IPS Kelas 4 SD/MI

\begin{tabular}{lll}
\hline Kelas & Pemetaan Konsep & Sistematika Materi \\
\hline Ruang & 1. Konsep Dasar Peta \\
& a. Pengertian peta \\
& b. Fungsi Peta \\
& c. Macam-macam Peta \\
& d. Komponen Peta \\
& e. Simbol Dasar Peta \\
& f. Membuat Peta Sederhana \\
& 2. Ruang \\
& a. Pengertian Ruang \\
& b. Karakteristik Ruang \\
& c. Interaksi antar Ruang \\
& \\
&
\end{tabular}




\section{Kelas Pemetaan Konsep}

\section{Sistematika Materi}

(complementarity)

2) Kesempatan antara

(Intervening opportunity)

3) Kemudahan transfer (transferability)

3. Sumber Daya Alam

a. Pengertian Sumber Daya

Alam

b. Sumber Daya Alam dibagi:

1) Berdasarkan Sifat

a) Sumber daya alam dapat diperbaharui

b) Sumber daya alam tidak dapat diperbaharui

2) Berdasarkan Jenis

a) Hayati

1.1) Hewani

1.2) Nabati

b) Abiotik

3) Berdasarkan bentuk
a) Energi
b) Materi
c) Ruang
d) Waktu

4) Berdasarkan Daya Pakai \& Ekonomis
a) Ekonomis
b) Non Ekonomis

5) Berdasarkan Lokasi
a) Akuatik
b) Terrestrial

Keragaman sosial,
ekonomi, budaya, etnis,
dan agama

Keragaman

dan agama
1. Pengertian Keragaman, Kesetaraan, dan Kesederajatan

2. Keragaman Sosial Budaya a. Keragaman Suku Bangsa 


\section{Kelas Pemetaan Konsep}

\section{Sistematika Materi}

b. Keragaman Sistem

Kekerabatan

c. Keragaman Budaya

1) Bahasa Daerah

2) Adat Istiadat

3) Bentuk Rumah Adat

4) Kesenian Daerah

5) Pakaian Adat

6) Senjata Tradisional

7) Makanan khas daerah

8) Lagu-lagu daerah

9) Permainan tradisional

3. Keragaman Ekonomi

1. Bidang pertambangan

2. Bidang perdagangan

3. Bidang pertanian dan perkebunan

4. Bidang industri

5. Bidang jasa

4. Keragaman Etnis

5. Keragaman Agama

6. Menghargai keragaman masyarakat Indonesia
Kegiatan ekonomi

Pekerjaan
1. Konsep Dasar Ekonomi

a. Sejarah Pemikiran Ekonomi

b. Pengertian Ekonomi

c. Prinsip Ekonomi

d. Motif Ekonomi

e. Tindakan Ekonomi

2. Kegiatan Ekonomi

a. Konsumsi

b. Produksi

c. Distribusi

1. Ketersediaan sumber-sumber ekonomi

2. Berbagai Pekerjaan 


\begin{tabular}{ll}
\hline Kelas Pemetaan Konsep & Sistematika Materi \\
\hline 3. & Kegiatan Ekonomi dan Lapangan \\
& Kerja \\
4. & Lembaga Ekonomi \\
5. & Perniagaan untuk meningkatkan \\
& kesejahteraan
\end{tabular}

Kerajaan Hindu

Kerajaan Budha

Kerajaan Islam
1. Konsep dasar Sejarah

a. Pengertian Sejarah

b. Peran \& Fungsi Sejarah

c. Pengelompokkan Sejarah

d. Nilai Kegunaan Sejarah

2. Kerajan Hindu Buhda Indonesia

a. Kutai

b. Tarumanegara

c. Mataram Kuno

d. Sriwijaya

e. Singosari

f. Majapahit

3. Kerajaan Islam Indonesia

a. Samudara Pasai

b. Demak

c. Mataram

d. Ternate

e. Tidore

f. Banten

g. Goa Tallo

h. Banjar

4. Pengaruh Kerajaan Hindu, Budha, dan Islam di Indonesia

Tabel 7 Pengembangan Sistematika Materi IPS Kelas 5 SD/MI

\begin{tabular}{lll}
\hline Kelas & Pemetaan Konsep & Sistematika Materi \\
\hline \multirow{4}{*}{5} & Karakter Geografis & 1. Letak dan Luas Indonesia dalam \\
Negara & Repulauan/maritim dan & a. Leta \\
& agraris & b. Letak Geografis \\
& & c. Letak Geologis
\end{tabular}




\begin{tabular}{|c|c|c|}
\hline Kelas & Pemetaan Konsep & Sistematika Materi \\
\hline & & $\begin{array}{l}\text { 2. Kondisi Alam Wilayah Indonesia } \\
\text { a. Keadaan iklim } \\
\text { b. Geologi } \\
\text { c. Bentuk muka bumi } \\
\text { 3. Karakteristik Kependudukan } \\
\text { a. Jumlah penduduk } \\
\text { b. Kepadatan penduduk } \\
\text { c. Persebaran penduduk } \\
\text { d. Pertumbuhan penduduk } \\
\text { 4. Negara Kepulauan/maritim dan } \\
\text { Agraris } \\
\text { 5. Pengaruh negara maritim dan } \\
\text { agraris terhadap kehidupan sosial } \\
\text { ekomomi dan budaya Indonesia }\end{array}$ \\
\hline & $\begin{array}{l}\text { Interaksi manusia dan } \\
\text { lingkungan } \\
\text { Pembangunan sosial, } \\
\text { budaya, dan ekonomi }\end{array}$ & $\begin{array}{l}\text { 1. Interaksi sosial budaya } \\
\text { a. Interaksi manusia dengan } \\
\text { lingkungan sosial } \\
\text { 1) Imitasi } \\
\text { 2) Sugesti } \\
\text { 3) Identifikasi } \\
\text { 4) Simpati } \\
\text { b. Interaksi manusia dengan } \\
\text { lingkungan budaya } \\
\text { 2. Sosialiasi } \\
\text { a. Fungsi Sosialisasi } \\
\text { b. Tujuan Sosialisasi } \\
\text { c. Faktor yang mempengaruhi } \\
\quad \text { Sosialisasi } \\
\text { d. Tahapan, jenis, dan media } \\
\text { sosialisasi } \\
\text { 3. Enkulturasi } \\
\text { 4. Pembangunan sosial budaya dan } \\
\text { ekonomi }\end{array}$ \\
\hline & $\begin{array}{l}\text { Penjajahan } \\
\text { Mempertahankan }\end{array}$ & $\begin{array}{l}\text { 1. Konsep dasar imperialisme dan } \\
\text { kolonialisme }\end{array}$ \\
\hline
\end{tabular}




\begin{tabular}{|c|c|c|}
\hline Kelas & Pemetaan Konsep & Sistematika Materi \\
\hline & kemerdekaan & $\begin{array}{l}\text { 2. Sejarah bangsa Eropa di Indonesia } \\
\text { 3. Penjajahan bangsa Eropa di } \\
\text { Indonesia } \\
\text { 4. Perlawanan bangsa Indonesia } \\
\text { 5. Organisasi gerakan Nasional } \\
\text { a. Budi Utomo } \\
\text { b. Serikat Islam } \\
\text { c. Indische Partij } \\
\text { d. Taman Siswa } \\
\text { e. Muhammadiyah } \\
\text { f. Nahdlatul Ulama } \\
\text { 6. Pendudukan militer Jepang di } \\
\text { Indonesia } \\
\text { 7. Pahlawan Nasional Indonesia }\end{array}$ \\
\hline
\end{tabular}

Tabel 8 Pengembangan Sistematika Materi IPS Kelas 6 SD/MI

\begin{tabular}{|c|c|c|}
\hline Kelas & Pemetaan Konsep & Hasil Pengembangan \\
\hline & Karakteristik & 1. Negara-negara ASEAN \\
\hline & Geografis & a. Sejarah ASEAN \\
\hline & Asean & b. Prinsip utama ASEAN \\
\hline & & c. Lambang ASEAN \\
\hline & & $\begin{array}{l}\text { 2. Karakteristik Geografis Wilayah } \\
\text { ASEAN }\end{array}$ \\
\hline & & $\begin{array}{l}\text { 3. Karakteristik kondisi alam Kawasan } \\
\text { ASEAN }\end{array}$ \\
\hline 6 & & $\begin{array}{l}\text { 4. Posisi Asia Tenggara ditinjau dari } \\
\text { Aspek Politik, Ekonomi, Sosial, dan } \\
\text { Budaya }\end{array}$ \\
\hline
\end{tabular}

Perubahan Sosial

Modernisasi
1. Perubahan Sosial Budaya di Indonesia

2. Modernisasi dalam bidang IPTEK, Ekonomi, Pendidikan, dan Demokrasi

3. Dampak Perubahan Sosial terhadap pola piker 


\begin{tabular}{|c|c|c|}
\hline Kelas & Pemetaan Konsep & Hasil Pengembangan \\
\hline & $\begin{array}{l}\text { Kerjasama negara- } \\
\text { negara ASEAN }\end{array}$ & $\begin{array}{l}\text { 1. Ekspor dan Impor } \\
\text { 2. Pengiriman Pertukaran Tenaga } \\
\text { Kerja } \\
\text { 3. Masyarakat Ekonomi ASEAN }\end{array}$ \\
\hline & $\begin{array}{l}\text { Proklamasi } \\
\text { kemerdekaan }\end{array}$ & $\begin{array}{l}\text { 1. Proklamasi Kemerdekaan } \\
\text { 2. Membangun kehidupan bangsa } \\
\text { yang berdaulat } \\
\text { 3. Perjuangan mempertahankan } \\
\text { Kemerdekaan Melalui Perang } \\
\text { Kemerdekaan I dan II } \\
\text { 4. Perjanjian renville, Linggar Jati, } \\
\text { Konferensi Meja Bundar } \\
\text { 5. Membangun Kehidupan } \\
\text { Kebangsaan yang Berdaulat } \\
\text { 6. Peran bangsa Indonesia dalam } \\
\text { membangun masyarakat } \\
\text { Internasional } \\
\text { a. Gerakan Non-Blok } \\
\text { b. Perserikatan Bangsa-Bangsa } \\
\text { (PBB) } \\
\text { c. Konferensi Asia Afrika (KAA) }\end{array}$ \\
\hline
\end{tabular}

\section{Penyajian Data Uji Coba}

Data yang disajikan, yaitu data yang diperoleh dari validasi kelayakan produk dari ahli materi, ahli Bahasa, dan ahli desain. Pada tahapan ini, para ahli yang telah ditentukan diberikan instrument dengan kesesuaian kategori dan print out produk desain pengembangan buku ajar Pendidikan IPS untuk menelaah dan memberikan evaluasi konstruktif. Skala yang digunakan dengan rentang 1 sampai dengan 5, di mana 1 berarti skor terendah, dan 5 skor tertinggi.

Skor tertinggi dari instrumen adalah lima (5), sedangkan skor terendah adalah satu (1). Pentingnya proses validasi dan uji coba adalah untuk mengetahui persepsi para ahli dan pengguna tentang produk buku ajar yang dikembangkan. Selanjutnya hasil persepsi atau tanggapan diolah menggunakan skala likert. Berikut dipaparkan data hasil 
penilaian validasi kelayakan produk pengembangan buku ajar Pendidikan IPS dengan Expanding Community Approach.

\section{Uji Coba kepada Ahli Materi Pelajaran}

Komponen angket yang diberikan kepada ahli materi pembelajaran berupa; cakupan materi, akurasi materi, kemutakhiran, merangsang keingintahuan, mengembangkan kecakapan hidup (life skill), dan mengandung wawasan kontekstual. Jumlah item pertanyaan pada angket berjumlah 21 pertanyaan, dengan hasil tertinggi skor adalah 105 dan terendah adalah 21. Jumlah skor jawaban yang diperoleh dari hasil uji coba kepada ahli materi adalah 85. Berangkat dari skor tersebut, maka dapat digunakan rumus persentase untuk menghitung skor dari ahli materi, yaitu 86,15\% (85: $105 \times 100 \%$ ). Secara kriterium dapat digambarkan sebagai berikut.

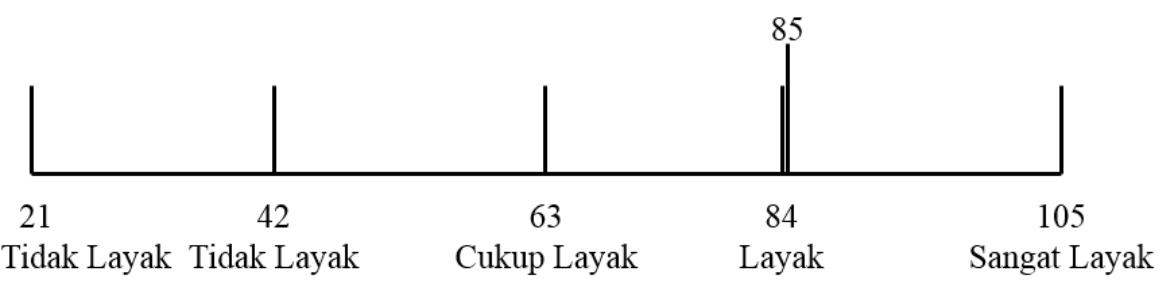

Sangat Tidak Layak Tidak Layak $\quad$ Cukup Layak $\quad$ Layak
Skor 85 yang diperoleh jika mengacu kepada kriterium, maka produk desain pengembangan buku ajar Pendidikan IPS mendapat kriteria layak, dan setelah melakukan revisi sesuai masukan dari ahli materi, tidak perlu dilakukan validasi kembali.

\section{Uji Coba kepada Ahli Bahasa}

Komponen angket yang diberikan kepada ahli Bahasa berupa; kesesuaian bahasa dengan perkembangan mahasiswa, komunikatif, dialogis dan interaktif, kelugasan bahasa, keruntutan alur pikir, koherensi, kesesuaian dengan bahasan Indonesia yang benar, penggunaan istilah dan symbol atau lambang. Jumlah item pertanyaan untuk ahli bahasa terhadap produk pengembangan buku ajar Pendidikan IPS berjumlah 20 item pertanyaan, dengan skor tertinggi 100 dan skor paling rendah adalah 20. Jumlah skor yang diperoleh dari tanggapan ahli Bahasa adalah 80. Berangkat dari skor tersebut, maka dapat digunakan rumus persentase untuk menentukan tingkat kriteria dari ahli bahasa, yaitu $=80 \%(80: 100 \times 100 \%)$. Secara kriterium dapat digambarkan sebagai berikut. 


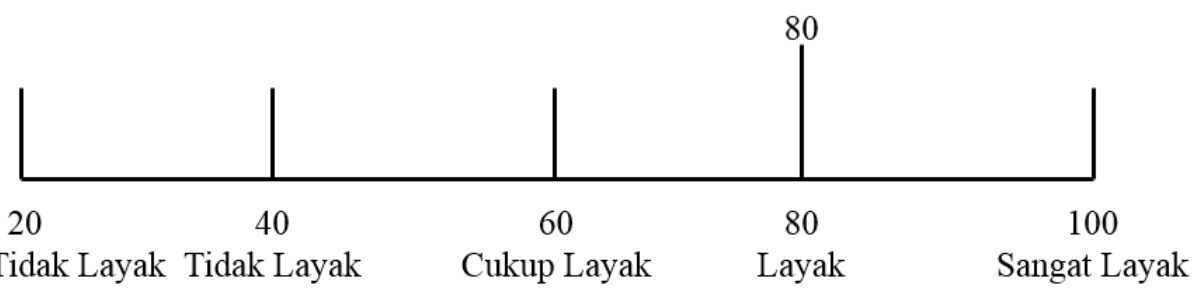

Skor 80 yang diperoleh jika mengacu kepada kriterium, maka produk desain pengembangan buku ajar Pendidikan IPS mendapat kriteria Layak dari ahli bahasa, dan setelah dilakukan revisi sesuai masukan dari ahli Bahasa, tidak perlu direvisi kembali.

\section{Uji Coba kepada Ahli Desain}

Komponen angket yang diserahkan kepada ahli desain berupa ukuran bahan ajar, desain sampul buku ajar, ilustrasi sampul buku ajar, desain isi buku, tipografi sampul dan isi buku ajar, tipografi isi buku ajar, ilustrasi dan gambar buku ajar, dan warna yang digunakan. Jumlah item pertanyaan yang diberikan kepada ahli desain tentang tanggapan buku ajar berjumlah 35 item pertanyaan, dengan skor tertinggi adalah 175 dan skor paling rendah adalah 35 . Jumlah skor dari ahli desain berjumlah 156, sehingga dapat digunakan rumus persentase yaitu = $87.64 \%$ (156: $175 \times 100 \%)$. Secara kriterium skor yang didapatkan dari ahli desain dapat digambarkan sebagai berikut.

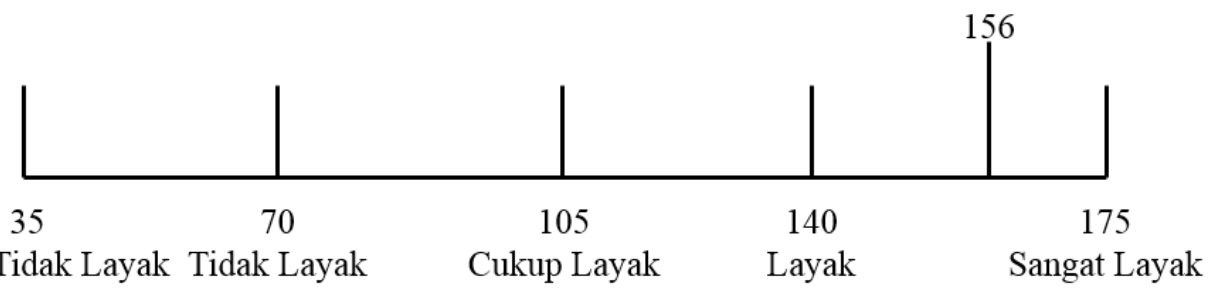

Sangat Tidak Layak Tidak Layak Cukup Layak Layak Sangat Layak

Skor 156 yang diperoleh dari ahli desain jika mengacu pada kriterium, maka produk desain pengembangan buku ajar Pendidikan IPS mendapat kriteria sangat layak. Setelah dilakukan revisi berdasarkan masukan dari ahli desain, maka tidak perlu melakukan revisi kembali.

Hasil kelayakan produk pengembangan buku ajar Pendidikan IPS untuk PGMI dengan Expanding Community Approach berdasarkan masukan dari ahli materi, ahli Bahasa, dan ahli desain dapat dilakukan rekapitulasi yang dapat dilihat pada tabel 9 . 
Tabel 9. Rekapitulasi Hasil Penilaian Validasi Ahli

\begin{tabular}{|c|c|c|c|c|c|c|c|c|c|}
\hline \multirow[b]{2}{*}{$\begin{array}{l}\mathbf{N} \\
\mathbf{0}\end{array}$} & \multirow{2}{*}{$\begin{array}{c}\text { Korespo } \\
\text { nden }\end{array}$} & \multirow[b]{2}{*}{$\begin{array}{l}\text { Sk } \\
\text { or }\end{array}$} & \multirow[b]{2}{*}{$\%$} & \multicolumn{5}{|c|}{ Kategori Tanggapan } & \multirow[b]{2}{*}{$\begin{array}{c}\text { Kesimp } \\
\text { ulan }\end{array}$} \\
\hline & & & & $\begin{array}{c}\mathbf{S L} \\
*\end{array}$ & $\begin{array}{c}\mathbf{L}^{*} \\
*\end{array}$ & $\underset{* *}{\mathbf{C L}}$ & $\begin{array}{c}\text { TL** } \\
\text { *** }\end{array}$ & $\underset{* * *}{\mathbf{S T L} * *}$ & \\
\hline 1 & $\begin{array}{l}\text { Ahli } \\
\text { Materi }\end{array}$ & 85 & $\begin{array}{l}8 \\
1 \\
\end{array}$ & $\sqrt{ }$ & - & - & - & - & $\begin{array}{l}\text { Tidak } \\
\text { revisi }\end{array}$ \\
\hline 2 & $\begin{array}{l}\text { Ahli } \\
\text { Bahasa }\end{array}$ & 80 & $\begin{array}{l}8 \\
0 \\
\end{array}$ & - & $\sqrt{ }$ & - & - & - & $\begin{array}{l}\text { Tidak } \\
\text { revisi }\end{array}$ \\
\hline 3 & $\begin{array}{l}\text { Ahli } \\
\text { Desain }\end{array}$ & $\begin{array}{c}15 \\
6 \\
\end{array}$ & $\begin{array}{l}8 \\
7\end{array}$ & $\sqrt{ }$ & - & - & - & - & $\begin{array}{l}\text { Tidak } \\
\text { revisi }\end{array}$ \\
\hline
\end{tabular}

*Sangat layak **Layak $\quad * * *$ Cukup Layak

*****Tidak Layak

*****Sangat Tidak Layak

Hasil rekapitulasi dari ahli tersebut menjadikan dasar bahwa produk pengembangan buku ajar Pendidikan IPS untuk PGMI dapat dikategorikan layak untuk dilakukan masuk ke tahap uji coba. Uji coba tidak dilakukan karena mata kuliah Pendidikan IPS akan tersedia di semester Ganjil. Pada semester akan dilakukan uji coba pada mahasiswa yang mengambil mata kuliah Pendidikan IPS, sehingga produk dapat digunakan pada pembelajaran terbatas, sebelum dilakukan uji coba terbuka pada jurusan PGMI di institusi lain.

\section{SIMPULAN}

Berdasarkan data yang telah didapatkan, maka Penelitian \& pengembangan ini bertujuan untuk 1) bagaimana mengembangkan buku ajar mata kuliah Pendidikan IPS MI/SD dengan pendekatan konsep berbasis kurikulum 2013; 2) mengetahui kelayakan buku ajar mata kuliah Pendidikan IPS MI/SD dengan pendekatan konsep berbasis kurikulum 2013 memenuhi kategori kelayakan skor 81\% dari ahli materi, $80 \%$ dari ahli bahasa, dan dengan skor $87 \%$ dari ahli desain. Penelitian dan pengembangan buku ajar Pendidikan IPS MI/SD ini akan dilanjutkan menggunakan pendekatan expanding community approach yang bertujuan menentukan tingkat keluasan materi berdasarkan pengembangan buku ajar IPS MI/SD menggunakan pendekatan konsep. 


\section{DAFTAR PUSTAKA}

Amin, Saiful. "Pengembangan Bahan Ajar Geografi Terintegrasi Sains Islam di Madrasah." Jurnal Pendidikan: Teori, Penelitian, dan Pengembangan 2, no. 7 (July 1, 2017): 934-45. https://doi.org/10.17977/jptpp.v2i7.9676.

Barr, Robert D, James L Barth, and S Samuel Shermis. Defining the Social Studies. National Council for the Social Studies Washington, DC, 1977.

Dewi, Anastasia Endah Anastika, and Mukminan Mukminan. "Implementasi Pendekatan Saintifik Dalam Pembelajaran IPS Di Middle Grade SD Tumbu 3 Kota." Jurnal Prima Edukasia 4, no. 1 (February 9, 2016): 20-31. https://doi.org/10.21831/jpe.v4i1.7691.

Islamy, M. Irfan. "Developing Concept Approach Based Textbooks of Social Sciences Course for Madrasah Ibtidaiyah Teacher Education." Al Ibtida: Jurnal Pendidikan Guru MI 6, no. 1 (June 30 , 2019): 90-109. https://doi.org/10.24235/al.ibtida.snj.v6i1.3594.

Jacobsen, David A, Paul D Eggen, and Donald P Kauchak. Methods for Teaching: Promoting Student Learning. Merrill/Prentice Hall, 2002.

Krismawati, Nia Ulfia, Warto Warto, and Nunuk Suryani. "Analisis Kebutuhan pada Bahan Ajar Penelitian dan Penulisan Sejarah di Sekolah Menengah Atas (SMA)." Briliant: Jurnal Riset dan Konseptual 3, no. 3 (August 13, 2018): 300-311. https://doi.org/10.28926/briliant.v3i3.202.

Lukman, Lukman, and Ishartiwi Ishartiwi. "PENGEMBANGAN BAHAN AJAR DENGAN MODEL MIND MAP UNTUK PEMBELAJARAN ILMU PENGETAHUAN SOSIAL SMP." Jurnal Inovasi Teknologi Pendidikan 1, no. 2 (2014): 109-22. https://doi.org/10.21831/tp.v1i2.2523.

Miftahuddin, Miftahuddin. "Revitaslisasi IPS Dalam Perspektif Global." Jurnal Pemikiran Keislaman 27, no. 2 (September 5, 2016): $267 \quad \sim \quad 284-267 \quad \sim \quad 284$. https://doi.org/10.33367/tribakti.v27i2.269.

Mosik -, and P. Maulana. "Usaha Mengurangi Terjadinya Miskonsepsi Fisika Melalui Pembelajaran dengan Pendekatan Konflik 
Kognitif.” Jurnal Pendidikan Fisika Indonesia 6, no. 2 (2010). https://doi.org/10.15294/jpfi.v6i2.1120.

Muna, Izza Auliyatul. "Identifikasi Miskonsepsi Mahasiswa PGMI

Pada Konsep Hukum Newton Menggunakan Certainty of Response Index (CRI)." Cendekia: Jurnal Kependidikan Dan Kemasyarakatan 13, no. 2 (April 4, 2016): 309-22. https://doi.org/10.21154/cendekia.v13i2.251.

Mursalin. "Meminimalkan Miskonsepsi Pada Materi Rangkaian Listrik Dengan Pembelajaran Predict-Observe-Explain." Jurnal Ilmu Pendidikan 20 , no. (2014).

https://doi.org/10.17977/jip.v20i1.4383.

Nurjannah, Nurjannah. "Pengembangan Pembelajaran IPS Berwawasan Kebangsaan Sebagai Matakuliah Jati Diri Di Fakultas Ilmu Sosial UNIMED." JUPIIS: JURNAL PENDIDIKAN ILMUILMU SOSIAL 9, no. 2 (December 28, 2017): 133-40. https://doi.org/10.24114/jupiis.v9i2.8241.

Prasetiyo, Nugroho Aji, and Pertiwi Perwiraningtyas. "The Development of Environment based Textbook in Biology Course at Tribhuwana Tunggadewi University." Jurnal Pendidikan Biologi Indonesia 3, no. 1 (March 31, 2017): 19. https://doi.org/10.22219/jpbi.v3i1.3969.

Puspitasari, Ratna. "Penanaman Nilai Karakter Peduli Lingkungan Dalam Muatan Enviromental Education Pada Pembelajaran IPS DI MI Darul Hikam Kota Cirebon." Al Ibtida: Jurnal Pendidikan Guru MI 3, no. 1 (June 10, 2016). https://doi.org/10.24235/al.ibtida.snj.v3i1.547.

Riwanda, Agus, Armin Fani, and M Irfan Islamy. "A CORRELATION BETWEEN THE USE OF INTERNET AS LEARNING SOURCE, LEARNERS'LEARNING AUTONUMOUS AND LEARNERS'ENGAGEMENT IN LEARNING PROCESS," 2:299-307, 2017.

Rohmah, Dina Fitrohtur, Hariyono Hariyono, and Sudarmiatin Sudarmiatin. "Pengembangan Buku Ajar IPS SD Berbasis Kontekstual." Jurnal Pendidikan: Teori, Penelitian, dan Pengembangan 2, no. 5 (May 1, 2017): 719-23. https://doi.org/10.17977/jptpp.v2i5.9200.

Ross, E Wayne. Social Studies Curriculum, The: Purposes, Problems, and Possibilities. Suny Press, 2014. 
Sapriya, Dr. "Pendidikan IPS." Bandung: PT. Remaja Rosdakarya, 2009.

Surahman, Edy, and M. Mukminan. "Peran guru IPS sebagai pendidik dan pengajar dalam meningkatkan sikap sosial dan tanggung jawab sosial siswa SMP." Harmoni Sosial: Jurnal Pendidikan IPS 4, no. 1 (October 16, 2017): 1. https://doi.org/10.21831/hsjpi.v4i1.8660.

Susilaningsih, Endang, Kasmui Kasmui, and Harjito Harjito. "Desain Instrumen Tes Diagnostik Pendeteksi Minkonsepsi Untuk Analisis Pemahaman Konsep Kimia Mahasiswa Calon Guru." Unnes Science Education Journal 5, no. 3 (2016). https://doi.org/10.15294/usej.v5i3.13184.

Suwarni, Erna. "PENGEMBANGAN BUKU AJAR BERBASIS LOKAL MATERI KEANEKARAGAMAN LABA-LABA DI KOTA METRO SEBAGAI SUMBER BELAJAR ALTERNATIF BIOLOGI UNTUK SISWA SMA KELAS X." BIOEDUKASI (Jurnal Pendidikan Biologi) 6, no. 2 (November 1, 2015). https://doi.org/10.24127/bioedukasi.v6i2.336.

Thiagarajan, Sivasailam. "Instructional Development for Training Teachers of Exceptional Children: A Sourcebook.," 1974.

Wijayati, Eni Cahya, I. Nyoman Sudana Degeng, and Sumarmi Sumarmi. "Kesulitan-Kesulitan dalam Implementasi Kurikulum Mata Pelajaran IPS SMP.” Jurnal Pendidikan: Teori, Penelitian, dan Pengembangan 1, no. 11 (November 1, 2016): 2241-47. https://doi.org/10.17977/jp.v1i11.8132. 